\title{
CALCULATION OF MAXIMUM WAVE RUN-UP AND EROSION AT VARNA REGIONAL COAST (WESTERN BLACK SEA) USING EMPIRICAL MODELS
}

\author{
Petya Eftimova ${ }^{1}$, Nikolay Valchev ${ }^{1}$, Nataliya Andreeva ${ }^{1}$, \\ Bogdan Prodanov ${ }^{1}$ and Liubomir Dimitrov ${ }^{1}$
}

\begin{abstract}
European coasts suffer significantly from hazards caused by low-probability and high-impact hydro-meteorological events. The aim of the study is to assess in probabilistic terms the magnitude of storm-induced flooding and erosion hazards along Varna regional coast (Bulgaria, western Black Sea). The study is performed employing the Coastal Risk Assessment Framework (CRAF) developed within EU FP7 RISC-KIT project. It constitutes a screening process that allows estimation of relevant hazard intensities and extents within predefined sectors. Since total water level was the chief property considered for determination of coastal flooding hazard, the accurate calculation of maximum wave induced run-up is of utter importance. Therefore, a central part of the study is testing the applicability and validation of three empirical models - from which the Holman model was preferred to be applied on sandy beaches, as well as EurOtop formulation for artificial or rocky slopes. As for erosion hazard, the performance of the convolution model was assessed and subsequently employed for evaluation of shoreline retreat. Quantification of hazard intensities allowed hinterland extent to be roughly delineated. As a final result of the study, hazard indicators were obtained for both flooding and erosion, which were subsequently mapped and used for identification of the most susceptible sectors along the regional coast. It was found that their concentration is highest in Varna Bay.
\end{abstract}

Keywords: coastal storms; maximum wave run-up; flooding hazard; shoreline retreat; erosion hazard; empirical models

\section{INTRODUCTION}

Severe storms are able to induce flooding and erosion hazards in coastal areas through high surges and wave action. These phenomena can be highly destructive and poses a threat on beaches - berms can be eroded and dunes washed out, on manmade environment - buildings and infrastructure along the coast can be destroyed, and huge areas of the hinterland can be inundated causing severe damages. In order to cope with such unfavorable events coastal managers and stakeholders should have information about the possible limits of the hazard extremities.

The present study focuses on assessment of the coastal flooding and erosion hazards caused by the extreme storms on a regional scale in order to identify the most vulnerable spots along the coast. It is performed as initial evaluation in the scope of hazard module of Coastal Risk Assessment Framework (CRAF) developed within EC FP7 project RISC-KIT (Resilience-Increasing Strategies for Coasts toolKIT) project (van Dongeren et al. 2016). Briefly, this framework constitutes a screening process that allows delimitation of susceptible alongshore sectors by assessing relevant hazard intensities and extents. This assumes sufficiently accurate reproduction of existing (or projected) spatial variability of both coastal morphology and hydro-meteorological forcing in terms of extreme storm events. The latter provides different combinations of boundary conditions that result in certain response to a hazard. Eventually, the variety of estimated responses (representing entire range of natural variability of coastal hazard for all tested conditions) gives possibility to perform a probabilistic analysis on the obtained coastal impact dataset (Ferreira et al. 2016). The main outcome is the probability distribution function of a given hazard that allows hazard parameters of interest to be directly evaluated. The assessment of hazard intensities is performed using empirical models. Since total water level was the chief property considered for determination of coastal flooding hazard, the accurate calculation of maximum wave induced run-up is of utter importance.

The majority of the incident wave energy dissipates across the surf zone by wave breaking and produce run-up on the foreshore of the beach. The wave run-up is important for coastal planers and engineers since it delivers the major part of the energy responsible for dune and beach erosion (Ruggiero et al. 2001, Sallenger 2000).

Existing time-dependent numerical models provide accurate, deterministic estimates of hydrodynamics and morphodynamics in the nearshore area but the regional scale of the study necessitates use of simplified expressions for wave run-up and beach erosion in probabilistic models for a range of surge and wave forcing and morphological conditions. There are number of empirical formulations for calculation of wave run-up based on statistical analysis of data gained in field experiments on natural beaches covering wide range of conditions among which are the formulations of

\footnotetext{
${ }^{1}$ Coastal Zone Dynamics Department, Institute of Oceanology - Bulgarian Academy of Sciences, 40 Parvi May Blvd., Varna, 9000, Bulgaria, e-mail: eftimova@io-bas.bg
} 
Hunt (1959), Battjes (1971), Holman (1986), Mase (1989), Douglass (1992), Stockdon et al. (2006), and Park and Cox (2015).

Two classical approaches exist to estimate the effect of high waves and water levels during a storm on coastal dunes, namely the equilibrium profile approach (Vellinga 1986, Kriebel and Dean 1993) and the wave impact approach (Overton et al. 1987, 1994). Other analytical models calculating beach and dune erosion and connected shoreline retreat were developed by Bruun (1962), Edelman (1972), Dean and Maurmeyer (1983), Kobayashi (1987) and Larson et al. (2004). Amongst others the convolution model model of Kriebel and Dean (1993) were selected because of its wide recognition and wide range of applications. It proposes formulations for one-slope profile and for a berm with dune, which is suitable for the present study.

\section{STUDY SITE}

Varna regional coast is located at the western part of the Black Sea coast with approximate length of $70 \mathrm{~km}$. The Black Sea is an elliptical semi-closed basin of weak tides (about $8 \mathrm{~cm}$ ) with a complex orography located in South-eastern Europe. The regional coast is limited by cape Ekrene to the north and cape St. Atanas to the south and includes Varna Bay (Fig. 1). Northward of Varna Bay, the coast between cape Ekrene and cape St. George is presented by cliffs of variable height with adjacent beaches of different dimensions limited by rocky capes. In this part of the coast there are several seaside resorts: Golden sands, Holiday Club Riviera, Kabakum, Sunny day Co., St. Constantine \& St. Helena, and Euxinograd.

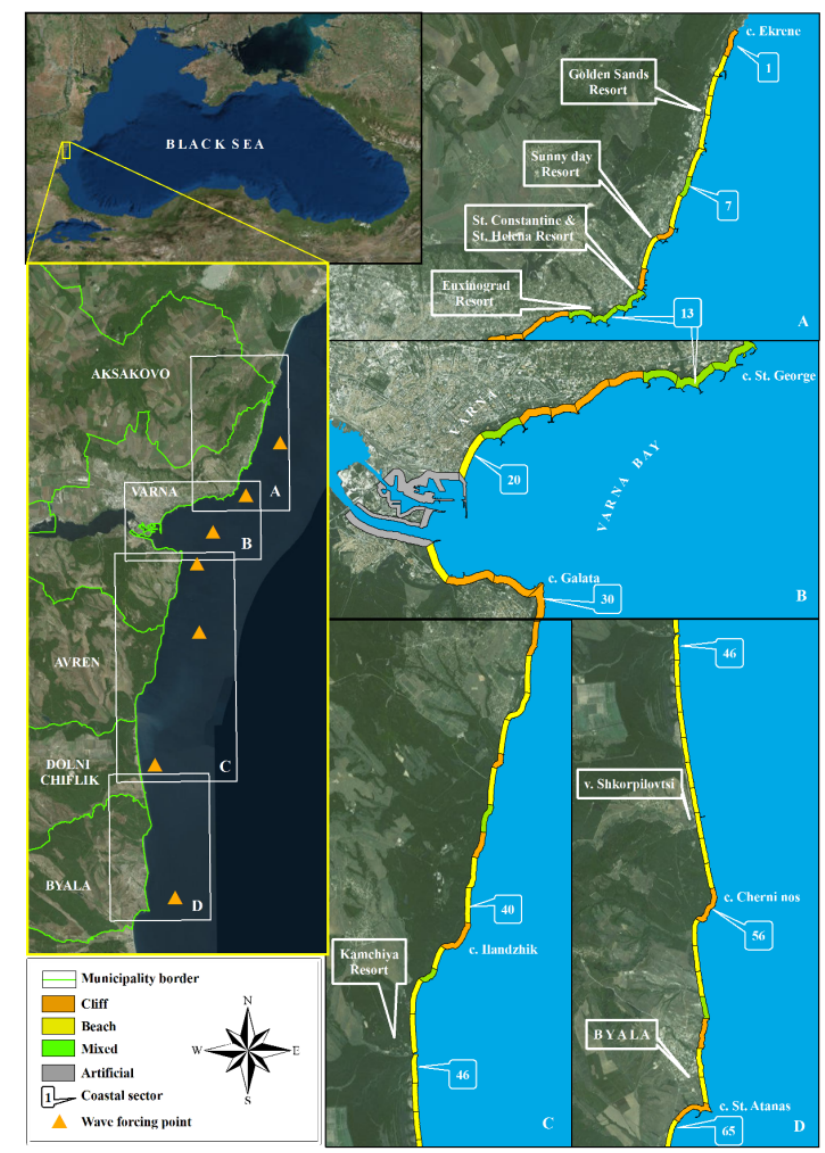

Figure 1. Schematic map of the study site indicating coast types within predefined sectors and location of grid points for wave forcing time series

The northern arm of Varna Bay is entirely protected by coastal defence structures, which resulted in formation of several beaches that nowadays alternate with rocky revetments. In the most inner curve of Varna Bay lays a sandy spit - a low-lying area cut by two artificial navigable canals connecting 
Varna bay to Varna Lake. This area holds the largest in Bulgaria transport and port agglomeration Varna-Beloslav-Devnya industrial complex.

Farther to the south, between cape Galata and cape Paletsa, the cliff reaches up to $125 \mathrm{~m}$ height. Between cape Paletsa and cape Cherni nos stretches the longest beach $(13 \mathrm{~km})$ along the Bulgarian Black Sea coast - Kamchia - Shkorpilovtsi, the only one in the case study site with dune presence. To the southward end of the site, between cape Cherni nos and cape St. Atanas, several narrow beaches are located that are backed by cliffs. Varna regional coast is exposed to severe storms hitting from the eastern half (Valchev et al. 2010).

\section{DATA AND METHODS}

Main coastal hazards considered in this study are coastal flooding and beach erosion. Generally, coastal flooding is caused by a combination of high water levels (storm surges plus high tides) and wave action (wave induced run-up). Since the Black Sea is considered a basin of weak tides, only storm surge and wave run-up were taken to form the total water level (TWL). In case of sheltered areas such as ports and canals only surge level component was taken into account. On the other hand, the assessment of storm-induced beach and dune erosion was performed based on calculation of shoreline retreat as a response of extreme storm events.

The methodology of the hazard assessment follows predefined steps: division of the Varna regional coast into sectors of comparable length; selection of cross-shore profiles representative for each sector; definition of extreme storm event; testing of ability of considered empirical models and selection of the most appropriate one; calculation of hazards' intensity at regional scale; definition of hazard extents in probabilistic terms; and finally, calculation of hazard indicators.

\section{Morphological setting}

The coast of Varna region has a variety of morphological settings and in order to assess the studied hazards it was divided into 65 coastal sectors of average length $\sim 1.1 \mathrm{~km}$ according to the predominant morphological setting. Of them 33 of sectors are sandy beaches ( 8 of which with presence of dunes), 14 are cliffs with narrow rocky beaches/slopes, and 11 are artificial (human modified). Due to the complexity of the coastal morphology and in order to maintain the sector length within the $\sim 1 \mathrm{~km}$ scale, 7 sectors comprises a mix of features i.e. rocky capes or coastal defence structures as groynes, rocky revetments with small beaches. Predominant coast types are shown as color coded strips corresponding to each sector (Fig. 1).

A high resolution Digital Elevation Model (DEM) is a prerequisite for reliable assessment of hazard intensities and resulting extents in the hinterland. Hence, such DEM, having mean sea level as reference datum, was created for the study area by means of the following components. The first one was ortophotogrametric digital surface model of $1 \mathrm{~m}$ horizontal and $10 \mathrm{~cm}$ vertical resolution available for two coastal areas: a strip located northward of Varna comprising several international seaside resorts (sectors 2-7) and Varna city coast (sectors 17-29) (Fig. 1). The topography of areas outside those high resolution domains was obtained from 1:5 000 topographic maps by digitizing contour lines up to $30 \mathrm{~m}$ a.m.s.l. (Stanchev et al. 2013). These sets were complemented by field measurements at several beaches situated within the study site and performed in 2010-2011. Shallow water bathymetry was generated using data from single-beam echo-sounder surveys. Thus, the resultant DEM has $1 \mathrm{~m}$ horizontal and $10 \mathrm{~cm}$ vertical resolution.

The total number of profiles considered is 159 as there are at least two profiles per sector - first one reflecting the predominant morphological conditions and second one reflecting the most vulnerable part of the sector in attempt to cover all possible hazard intensities. For the mixed sectors (beach or rocky/artificial slopes) a profile for each slope type was selected.

According to the morphodynamic classification of Wright and Short (1984), beaches along Varna regional coast are predominantly intermediate (with presence of longshore bar-trough) but there are also dissipative beaches, as those in the vicinity of Kamchia river, and reflective beaches exposed to high wave energy or located in areas with sediment supply shortage (due to disruption of long-shore sediment transport).

According to the profiles extracted from the DEM, slopes of natural and man-modified beaches are in the range of 0.01 and 0.26 , with average value of 0.11 . The beach sediments are characterized by mean sediment diameter $\mathrm{D}_{50}$ varying between 0.21 and $1.55 \mathrm{~mm}$. The natural rocky slopes and the slopes at coastal defence structures are in the range of $0.04 \div 0.56$. 


\section{Extreme event definition}

The assessment of extreme wave run-up, defined by the $2 \%$ exceedance value, and maximum beach erosion follow the response approach (Garrity et al. 2006) and requires definition and selection of extreme storm events and generation of storm surge and wave time series representative for each coastal sector.

Extreme events were determined using wave hindcast data covering 57-year period (1949-2006) (Valchev et al. 2012). Selected boundary condition points for extraction of wave climate time series are shown in Fig. 1. Storm surge data covering the same time-span was obtained by means of long-term tide gauge daily measurements at two locations - one in Varna Bay and the other one representative for the open shore conditions to the south of the bay.

Peak over threshold (POT) analysis was used to identify the individual coastal storms using threshold of $2 \mathrm{~m}$ for significant wave height, which should be exceeded for a time-span longer than 18 hours. The threshold for significant wave height was selected since it represents the 99 percentile, while duration was set on the basis of measured morphological impact of short-duration storms of equal intensity at two beaches within the study area. The impact was considered important in terms of thresholds established in Trifonova et al. (2012). After analysis, 144 storm events were selected and surge level, significant wave height and peak wave period maxima along with mean wave direction and storm duration were defined for each storm event.

Storm wave data at the selected locations are summarized in Table 1. It can be seen that the extreme ( $\min$ and $\max$ ) wave conditions exhibit a distinct spatial variability. Significant wave heights are in the range of $2 \div 5.8 \mathrm{~m}$, peak wave period $-5.1 \div 10.9 \mathrm{~s}$ and mean wave direction vary between $\mathrm{NNE}$ and ESE. As for the corresponding surge maxima measured at a coastal tide gauge they vary between 0.4 and $1.69 \mathrm{~m}$.

\begin{tabular}{|c|c|c|c|c|c|c|c|}
\hline Point No & $\begin{array}{c}\text { Point } \\
\text { depth, } m\end{array}$ & Sectors & $\begin{array}{c}\text { Minimum/ } \\
\text { maximum } \\
\text { value }\end{array}$ & $\begin{array}{c}H_{s}, \\
\mathrm{~m}\end{array}$ & $\begin{array}{c}T_{p} \\
\mathrm{~s}\end{array}$ & $\begin{array}{l}\text { Direction, } \\
\operatorname{deg} N\end{array}$ & $\begin{array}{l}\text { Duration, } \\
\text { hours }\end{array}$ \\
\hline 1 & 23 & $1 \div 9$ & $\begin{array}{l}\min \\
\max \end{array}$ & $\begin{array}{l}2.0 \\
4.2\end{array}$ & $\begin{array}{c}5.1 \\
10.9\end{array}$ & $\begin{array}{c}56 \\
111\end{array}$ & $\begin{array}{c}16 \\
126\end{array}$ \\
\hline 2 & 23 & $10 \div 13$ & $\begin{array}{l}\min \\
\max \end{array}$ & $\begin{array}{l}2.0 \\
4.6\end{array}$ & $\begin{array}{c}7.3 \\
10.7\end{array}$ & $\begin{array}{c}79 \\
109\end{array}$ & $\begin{array}{c}5 \\
135\end{array}$ \\
\hline 3 & 22 & $14 \div 29$ & $\begin{array}{l}\min \\
\max \end{array}$ & $\begin{array}{l}2.1 \\
4.8\end{array}$ & $\begin{array}{c}7.3 \\
10.7\end{array}$ & $\begin{array}{c}60 \\
106\end{array}$ & $\begin{array}{c}13 \\
139\end{array}$ \\
\hline 4 & 22 & $30 \div 33$ & $\begin{array}{l}\min \\
\max \end{array}$ & $\begin{array}{l}2.0 \\
4.8\end{array}$ & $\begin{array}{l}6.7 \\
10.7\end{array}$ & $\begin{array}{c}50 \\
102\end{array}$ & $\begin{array}{c}17 \\
144\end{array}$ \\
\hline 5 & 23 & $34 \div 41$ & $\begin{array}{l}\min \\
\max \end{array}$ & $\begin{array}{l}2.2 \\
5.4\end{array}$ & $\begin{array}{c}6.6 \\
10.6\end{array}$ & $\begin{array}{c}49 \\
101\end{array}$ & $\begin{array}{c}15 \\
158\end{array}$ \\
\hline 6 & 24 & $42 \div 56$ & $\begin{array}{l}\min \\
\max \end{array}$ & $\begin{array}{l}2.1 \\
4.8\end{array}$ & $\begin{array}{c}6 \\
10.7\end{array}$ & $\begin{array}{c}43 \\
107\end{array}$ & $\begin{array}{c}11 \\
136\end{array}$ \\
\hline 7 & 32 & $57 \div 65$ & $\begin{array}{l}\min \\
\max \end{array}$ & $\begin{array}{l}2.2 \\
5.8\end{array}$ & $\begin{array}{l}6.1 \\
10.7\end{array}$ & $\begin{array}{l}35 \\
95\end{array}$ & $\begin{array}{c}17 \\
166\end{array}$ \\
\hline
\end{tabular}

\section{Empirical models}

Three empirical models for calculation of extreme wave run-up on natural beaches were considered in attempt to identify the most suitable for Varna regional coast. These are the Holman model (Holman, 1986), the model of Nielsen and Hanslow (1991) and the Stockdon model (Stockdon et al. 2006).

The Holman model is based on field data covering wave heights from 0.4 to $4.0 \mathrm{~m}$, wave period from 6 to $16 \mathrm{~s}$, and beach face slope varying from 0.07 to 0.20 . The model predicts $2 \%$ exceedance value of the run-up magnitude, $R_{2 \%}$, as:

$$
R_{2 \%}=H_{s}(0.83 \xi+0.2)
$$

where $H_{s}$ is significant wave height in deep water, $\xi$-non-dimensional surf similarity parameter, called the Iribarren number (Battjes, 1974):

$$
\xi=\frac{\tan \beta}{\left(H_{S} / L_{0}\right)^{1 / 2}}
$$


where $\tan \beta$ is beach face slope, $H_{s}$ is the deepwater significant wave height, $L_{0}$ is the deepwater wave length associated to the wave peak period, $T_{p}$.

The Nielsen and Hanslow model is based on data covering wide range of natural sandy beach types - from highly reflective steep beach type to dissipative low gradient beach type. Deep water root mean square wave height $\left(H_{0 r m s}\right)$ from $0.53 \mathrm{~m}$ to $3.76 \mathrm{~m}$ and wave period range from 6.4 to $11.5 \mathrm{~s}$ were considered. Mean grain size of the beach is between $0.18 \mathrm{~mm}$ to $0.8 \mathrm{~mm}$. The model predicts the run-up magnitude, $R_{2 \%}$, as

$$
R_{2 \%}=1.98 L_{z w m}
$$

where:

$$
L_{\text {zwm }}=0.6\left(H_{0 r m s} L_{0}\right)^{1 / 2} \tan \beta \text { for } \tan \beta \geq 0.1
$$

For flatter beaches the beach face slope loses importance and the vertical scale of run-up distribution $\left(\mathrm{L}_{\mathrm{zwm}}\right)$ is proportional to the square root of deepwater wave steepness:

$$
L_{z w m}=0.05\left(H_{0 r m s} L_{0}\right)^{1 / 2} \text { for } \tan \beta \leq 0.1
$$

The Stockdon model was developed to calculate the extreme run-up on natural beaches over a wide range of conditions. The data used for parametrization represented mostly intermediate to reflective conditions $(0.3<\xi<4.0)$ but also covered dissipative conditions with mean significant wave heights varying form $0.7 \mathrm{~m}$ to $2.5 \mathrm{~m}$; deep water wave periods $-8 \div 14.9 \mathrm{~s}$ and beach face slopes $-0.08 \div 0.11$. $R_{2 \%}$ on all natural beaches is calculated through:

$$
R_{2 \%}=1.1\left(0.35 \tan \beta\left(H_{S} L_{0}\right)^{1 / 2}+\frac{\left[H_{S} L_{0}\left(0.563 \tan \beta^{2}+0.004\right)\right]^{1 / 2}}{2}\right)
$$

Under extremely dissipative conditions, $R_{2 \%}$ is estimated using dissipative-specific parameterization:

$$
R_{2 \%}=0.043\left(H_{s} L_{0}\right)^{1 / 2} \text { for } \xi<0.3
$$

Since there are a number of natural rocky slopes and armoured structures in the study site, the magnitude of $R_{2} \%$ was calculated using the EurOtop wave run-up model (Pullen et al., 2007). Formulations consider the effects of various slopes, roughness and permeability typical for natural rocky coastlines, armoured rubble slopes covered with variety of materials such as concrete blocks, tetrapodes, rocks of different sizes etc. The influence of wave attack is also included. According to the model the mean run-up value is calculated using:

$$
\frac{R u_{2} \%}{H_{s}}=1.65 \gamma_{b} \gamma_{f} \gamma_{\beta} \xi
$$

with a maximum of

$$
\frac{R u_{2 \%}}{H_{S}}=1.00 \gamma_{b} \gamma_{f \text { surging }} \gamma_{\beta} \xi\left(4.0-\frac{1.5}{\sqrt{\xi}}\right)
$$

where $\gamma_{b}$ is berm influence factor, $\gamma_{f}$ - surface roughness parameter, $\gamma_{\beta}$-influence factor of wave direction.

The beach erosion along the regional coast was assessed through the convolution model of Kriebel and Dean (1993). Two formulations were applied: one for a profile with sloping beach face and one for beach profile with a dune. The shoreline retreat was selected as a hazard indicator for beach erosion since different types of beaches were assessed.

Firstly, maximum potential retreat was calculated using the formula:

$$
R_{\infty}=\frac{s\left(x_{b}-\frac{h_{b}}{m}\right)}{B+h_{b}-\frac{s}{2}}
$$

where $R_{\infty}$ is maximum erosion potential, $x_{b}$ is surf zone width, $h_{b}$ - depth of wave breaking, $B$ - berm height, $\mathrm{s}$ - surge, and $m$ - beach face slope

Furthermore, the volume eroded above the mean sea level at equilibrium was calculated using:

$$
V_{m \infty}=R_{\infty} B+\frac{s^{2}}{2 m}-\frac{2}{5} \frac{s^{5 / 2}}{A^{3 / 2}}
$$


where $A$ is parameter governing the steepness of the profile.

Finally, the shoreline retreat was calculated using the formula:

$$
R(t)=0.5 R_{\infty}\left\{1-\frac{\beta^{2}}{1+\beta^{2}} \exp \left(-\frac{t}{T_{S}}\right)-\frac{1}{1+\beta^{2}}\left[\cos \left(\frac{2 \pi t}{T_{D}}\right)+\beta \sin \left(\frac{2 \pi t}{T_{D}}\right)\right]\right\}
$$

where $T_{S}$ is characteristic time scale of profile response, $T_{D}-$ storm duration.

Breaking wave height $\left(H_{b}\right)$ and depth of wave breaking $\left(h_{b}\right)$ were calculated following formulation given in Weggel (1972) and Komar and Gaughan (1973).

\section{Validation of empirical models}

The performance of Holman model, the model of Nielsen \& Hanslow and the Stockdon model were tested against topographic measurements at four sandy beaches within the study site domain Shkorpilovtsi beach, Asparukhovo beach, Varna central beach, Varna groynes beach for five storm events. The morphological dataset used for model validation consisted of pre- and post-storm topographic and shallow bathymetry profiles, and position of maximum wave run-up extent. The topography measurements were performed an autonomous Trimble ${ }^{\circledR}$ Site Positioning System with RTK corrections $(0.05 \mathrm{~m}$ horizontal and 0.07 vertical precision). The hydrodynamic dataset consisted of ADCP measurements at depths of $18 \div 22.5 \mathrm{~m}$ for all storm events, except for the one in March 2010 for which deepwater wave parameters are derived from wave hindcast (Valchev et al. 2012). Dataset is summarized in Table 2

Table 2. Deepwater wave parameters and beach morphological settings.

\begin{tabular}{|c|c|c|c|c|c|c|c|c|}
\hline Storm & Beach & $\begin{array}{l}\text { No } \\
\text { profiles }\end{array}$ & $\tan \beta$ & $\begin{array}{l}\text { Irribaren } \\
\text { number }\end{array}$ & $\begin{array}{l}\text { Max } \\
H_{s}, m\end{array}$ & $\begin{array}{l}\text { Max } \\
T_{p}, S^{*}\end{array}$ & $\begin{array}{l}\text { Max } \\
\text { storm } \\
\text { surge, m }\end{array}$ & $\begin{array}{l}\text { Max wave } \\
\text { run-up } \\
\text { elevation, m }\end{array}$ \\
\hline $03 / 2009$ & Shkorpilovtsi & 21 & $0.12 \div 0.23$ & $0.80 \div 1.56$ & 1.79 & 7.3 & 0.15 & $1.25 \div 2.80$ \\
\hline $11 / 2009$ & Shkorpilovtsi & 42 & $0.06 \div 0.18$ & $0.35 \div 1.14$ & 2.12 & 7.3 & 0.20 & $1.54 \div 2.93$ \\
\hline 03/2010 & Shkorpilovtsi & 20 & $0.06 \div 0.15$ & $0.35 \div 0.90$ & $4.17^{* *}$ & 9.6 & 0.70 & $2.29 \div 3.67$ \\
\hline $02 / 2015$ & Asparuhovo & 26 & $0.08 \div 0.23$ & $0.54 \div 1.52$ & 2.09 & 7.7 & 0.42 & $1.20 \div 2.51$ \\
\hline 03/2015 & Asparuhovo & 24 & $0.03 \div 0.13$ & $0.23 \div 0.92$ & 2.35 & 8.8 & 0.35 & $0.86 \div 1.87$ \\
\hline 03/2015 & Varna central & 23 & $0.09 \div 0.19$ & $0.67 \div 1.40$ & 2.35 & 8.8 & 0.35 & $1.63 \div 2.61$ \\
\hline $03 / 2015$ & Varna groynes & 20 & $0.05 \div 0.19$ & $0.33 \div 1.36$ & 2.35 & 8.8 & 0.35 & $0.96 \div 2.60$ \\
\hline
\end{tabular}

* value of $\mathrm{T}_{\mathrm{p}}$ corresponding to the $\mathrm{H}_{\mathrm{s}}$ maximum;** - modeled

The EurOtop wave run-up model was tested against field measurements data at coastal revetment in Varna Bay for the storm of February 2012. The artificial profiles were described by seaward slope steepness, freeboard (structure crest), profile orientation and roughness coefficient. Dataset is summarized in Table 3.

Table 3. Deepwater wave parameters and artificial slope settings.

\begin{tabular}{|llllllll}
\hline Storm & Location & $\begin{array}{l}\text { No } \\
\text { profiles }\end{array}$ & $\tan \beta$ & $\begin{array}{l}\text { Irribaren } \\
\text { number }\end{array}$ & $\begin{array}{l}\text { Max } \\
\mathrm{H}_{\mathrm{s}}, \mathrm{m}\end{array}$ & $\begin{array}{l}\text { Max } \\
\mathrm{T}_{\mathrm{p}}, \mathrm{s}\end{array}$ & $\begin{array}{l}\text { Max } \\
\text { storm } \\
\text { surge, } \mathrm{m}\end{array}$ \\
\hline $03 / 2009$ & Varna Bay & 3 & $0.27 \div 0.42$ & $1.49 \div 2.32$ & 4.1 & 9.0 & $\begin{array}{l}\text { Max wave } \\
\text { run-up } \\
\text { elevation, } \mathrm{m}\end{array}$ \\
\hline
\end{tabular}

* value of $\mathrm{T}_{\mathrm{p}}$ corresponding to the $\mathrm{H}_{\mathrm{s}}$ maximum; ${ }^{* *}$ - modeled

The convolution model was validated against field data for the storm of March 2010 at Shkorpilovtsi Beach. The storm event was characterized with maximum significant wave height of $4.17 \mathrm{~m}$ and peak period of $9.6 \mathrm{~s}$, eastern direction of storm propagation and duration of $39 \mathrm{~h}$ (Table 2). Pre-storm and post-storm topography, bathymetry and sediment data were used for calculation of the shoreline retreat on 20 beach profiles with slopes ranging between 0.06 and $0.15 . \mathrm{D}_{50}$ at the beach face were in the range of $0.35 \div 0.43 \mathrm{~mm}$. DEM of Shkorpilovtsi beach, measured pre- and -post storm shoreline, and the location of the profiles used for validation are presented in Fig. 2.

\section{Calculation of hazard intensity and extent on regional level}

Once the forcing along the coast has been defined, resultant hazard intensities (maximum total water level and shoreline retreat) were calculated using empirical models applicable to each type of coast presented at the study site. The run-up models were applied on 105 beach profiles and 54 rocky and artificial profiles. Series of total water levels were compiled for all profiles and for all historical storms in order to be used for storm-induced hazard analysis. 
On the other hand, the shoreline retreat was calculated using eqs. (10) - (12) applied on 105 beach profiles. Series of shoreline retreat were compiled for all beach profiles and for all historical storms.

The series of TWLs and shoreline retreats were subjected to Extreme Value Analysis and hazard intensities relevant to return periods of 20,50 and 100 years were further analyzed. These return periods were considered benchmark values by most of the regional stakeholders (Dimitrov et al. 2013).

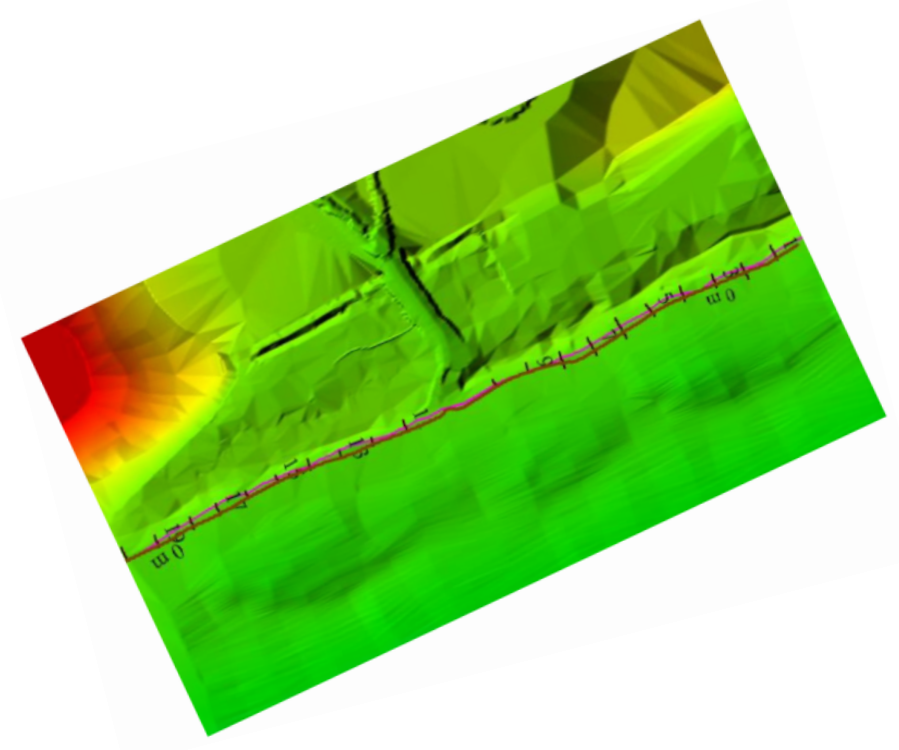

Figure 2. Digital elevation model of Shkorpilovtsi beach showing the river mouth along with pre-storm (brown line), post-storm (magenta line) shoreline and validation profiles.

The flooding hazard extents were determined using two approaches depending on the slope of the hinterland. In case of fast rising slopes "bathtub" approach was applied, while for law-laying hinterland areas overwash extent was calculated. "Bathtubbing" (or equilibrium flood mapping) is a simplified method that is often utilized to re-draw coastal flood zones method. It is essentially horizontal spreading of flood elevation data to areas of lower elevation (Orton et al. 2014). As for the overwash extent in the backbarrier zone following formulation was used (Donnelly, 2008):

$$
\mathrm{h}(\mathrm{x})=\mathrm{h}_{\mathrm{c}} \exp \left(-\mathrm{a} \frac{\mathrm{x}}{\mathrm{u}_{\mathrm{c}}}\right)
$$

where $h_{c}$ is the flood depth over the beach crest, $u_{c}$ - the flow velocity at the crest of the dune, and $a$ is the proportionality constant for infiltration. The whole impact extent is calculated through sum of the horizontal distance from SWL to the beach crest and the extent of the overwash in the backbarrier zone. Additionally, flooding hazard at the breakwater of Port of Varna was assessed using the overtopping formulation proposed in the model of Hedges and Reis (1998):

$$
\frac{\mathrm{Q}}{\sqrt{\mathrm{gR}_{\max }^{3}}}=\left\{\begin{array}{cr}
\mathrm{A}\left(1-\frac{\mathrm{Rc}}{\gamma_{\mathrm{r}} \mathrm{R}_{\max }}\right)^{\mathrm{B}} & 0 \leq \frac{\mathrm{Rc}}{\gamma_{\mathrm{r}} \mathrm{R}_{\max }}<1 \\
0 & \frac{\mathrm{Rc}}{\gamma_{\mathrm{r}} \mathrm{R}_{\max }} \geq 1
\end{array}\right.
$$

where $R_{\max }$ is the maximum wave run-up value during the storm, $\gamma_{r}$ is a roughness coefficient for the sloping bed (e.g. 1 for sand), $R_{c}$ is the beach freeboard (elevation of the berm/embankment relative to the mean water level), $A$ and $B$ are coefficients, which are given by Reis et al. (2008).

Regarding the beach erosion, the hazard extents for each sector were presented as a buffer zone of equal distance from the coastline according to the calculated probabilities. The flooded and eroded areas defined after calculation of hazard extents were presented in the form of polygons for further analysis. 


\section{RESULTS AND DISCUSSION}

\section{Model validation}

In order to select the most suitable model for calculation of maximum wave run-up on natural beach slopes, the three empirical models (Holman, Nielsen \& Hanslow and Stockdon) described above were applied using the validation dataset. An assessment of their ability was done by analyzing dependence between Irribaren number and $R_{2} \%$ normalized by $\mathrm{H}_{\mathrm{s}}$ (Fig. 3), dependence between $\tan \beta$ and TWLs (Fig. 4) and comparison between the measured and predicted TWLs (Fig. 5).
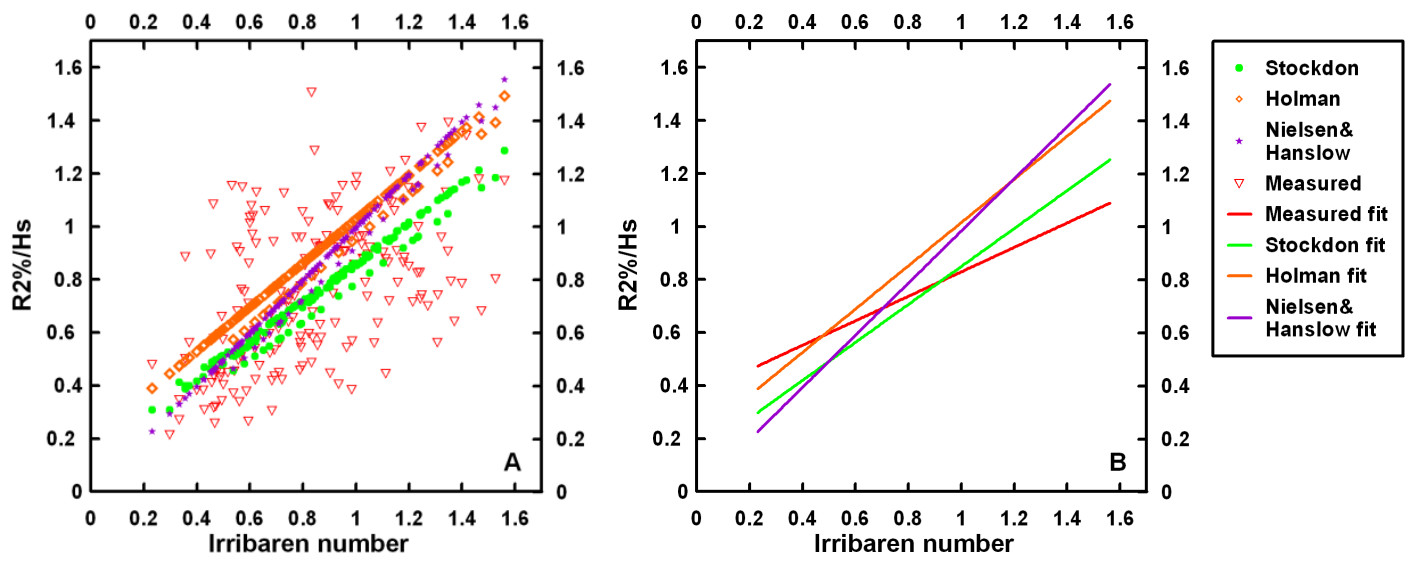

Figure 3. Dependence between Irribaren number and $\boldsymbol{R}_{2 \%}$ normalized by $\mathrm{H}_{\mathrm{s}}$ : data points (A), data fits (B)
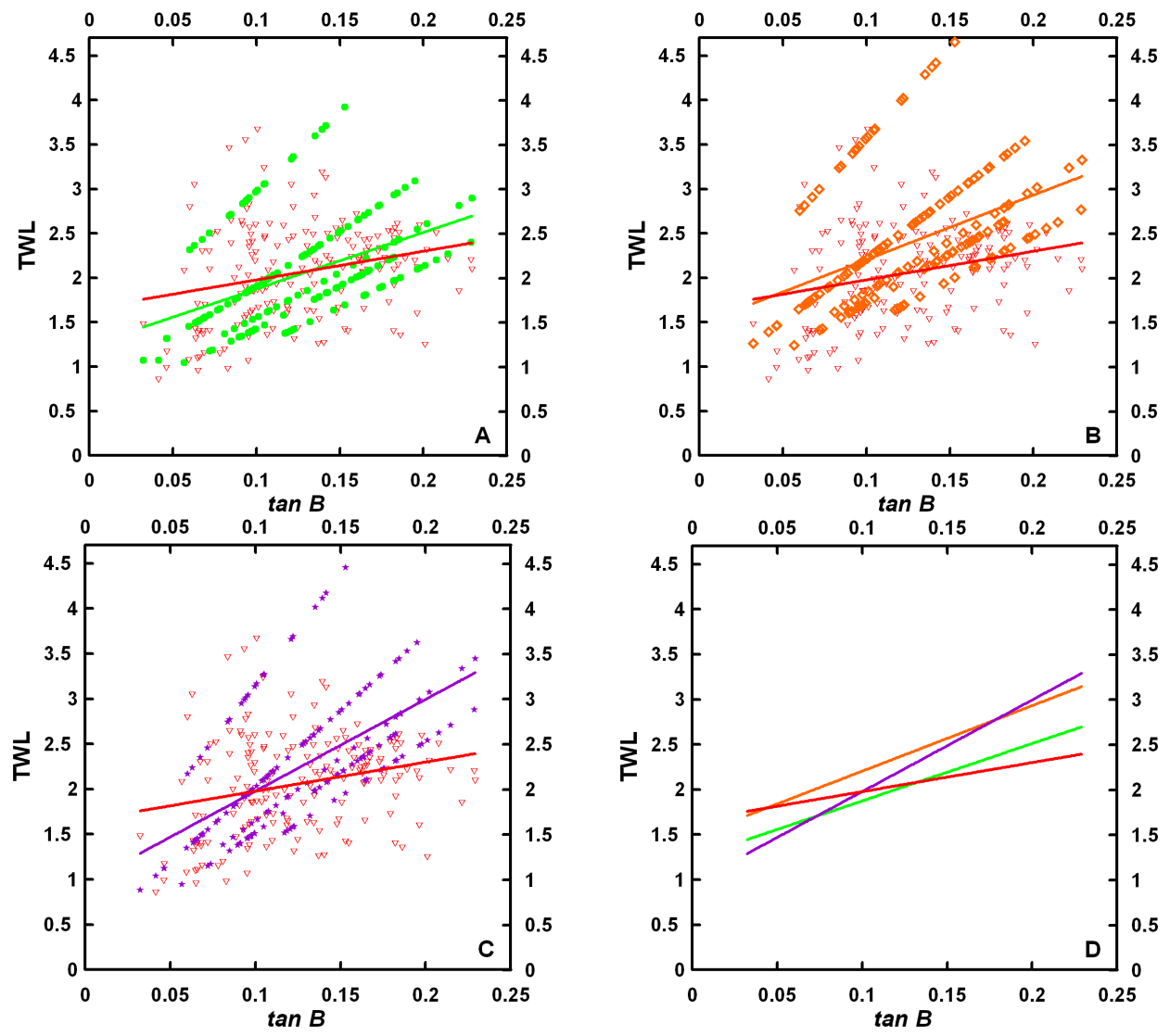

Figure 4. Dependence between $\tan \beta$ and TWLs: A) Measured (red triangles) vs. predicted TWLs by Stockdon model (green dots) and their fits; B) Measured (red triangles) vs. predicted TWLs by Holman model (orange rhomboids) and their fits; C) Measured (red triangles) vs. predicted TWLs by Nielsen \& Hanslow model (purple stars) and their fits; D) All TWLs fits placed together giving a better base for comparison. Legend is the same as in Fig. 3. 
The dependence between Irribaren number and measured/predicted normalized $R_{2 \%}$ shows that the three models tend to underestimate the run-up for dissipative and intermediate $(0.4<\xi<0.8)$ conditions and to overestimate the run-up for larger values of Irribaren number (i.e. for intermediate to reflective conditions). Nielsen \& Hanslow model shows the largest deviation in comparison to measurements, while the Stockdon model fits best to field data. On the other hand, the Holman model tends to underestimate wave run-up within the smallest range of conditions $(0.2<\xi<0.5)$. The wider dispersion of the measured data points around the area defined by predicted ones implies that there are more factors influencing the wave run-up than deepwater steepness and beach-face slope considered in the models.

The dependence between $\tan \beta$ and TWLs (Fig. 4A, D) shows that Stockdon model underestimates the TWL for small slopes $(\tan \beta<0.115)$ and overestimates the wave run-up for larger slopes. The model of Nielsen \& Hanslow (Fig. 4C, D) considerably underpredicts TWL for slopes smaller than 0.09, while for larger slopes the opposite is observed. Holman model (Fig. 4B, D) best copes with reproduction of observed TWL for small slopes but also tends to increasingly overestimate it as the beach slope grows, but still performs better than the model of Nielsen \& Hanslow for larger slopes. Comparing all fits (Fig. 4D) it can be claimed that the Holman model is the only one that does not underestimates wave run-ups.

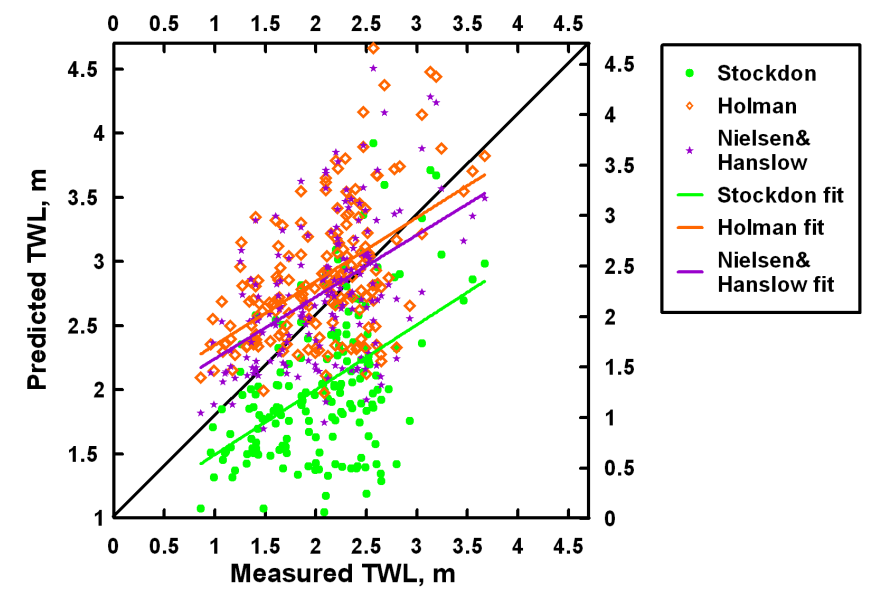

Figure 5. Comparison between predicted and measured TWLs

Comparison between measured and predicted TWLs shows that the Stockdon model considerably underestimates the TWLs for the whole range of field data, while the performance of the other two models is similar - they overestimate lower levels (TWL $<2.5 \mathrm{~m}$ ) and underestimate higher ones.

Furthermore, the calculated correlation coefficients between measured and predicted TWLs are as follows: 0.49 (Stockdon model), 0.52 (Holman model), 0.48 (Nielsen \& Hanslow model). This result tends to give a preference to the Holman model even if the difference between coefficients is not substantial.
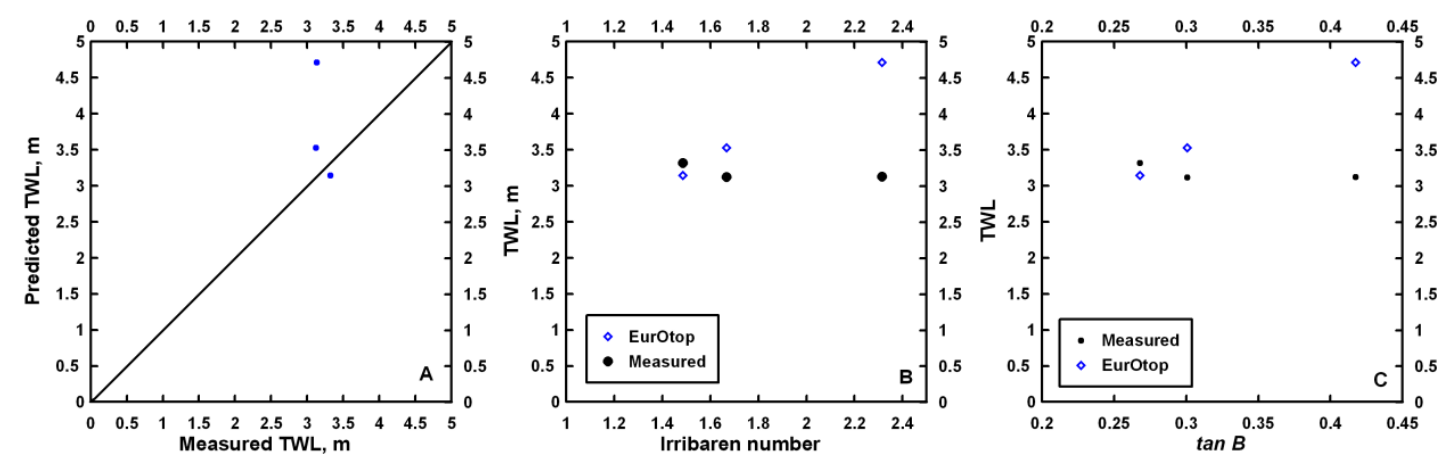

Figure 6. Comparison between the measured and predicted TWLs (A), Irribaren number against TWLs (B) and $\tan \beta$ against TWLs 
Clearly, the results are problematic for reflective conditions but there is very small difference between estimates obtained with Holman and Nielsen \& Hanslow models for those profiles. Based on these observations and particularly on the result of direct comparison between measured and predicted TWLs, the Holman model was selected as the most suitable one to be applied at Varna regional coast.

The EurOtop model was validated using available validation dataset. The obtained estimates of total water levels were compared with the measurements and related to $\tan \beta$ and Irribaren number (Fig. 6 ). It seems that for smaller tan $\beta$ and Irribaren number the model underestimates the value of $R_{2 \%}$ while considerably overestimates it for larger values. However, the tests were performed only at three profiles, which does not allow for unbiased judgment on the model applicability.

Concerning erosion, the convolution model was applied using the validation dataset obtained for Shkorpilovtci beach (Fig. 2). Analysis indicates that the measured shoreline retreat varied in wide range - between 2 and $11.6 \mathrm{~m}$.
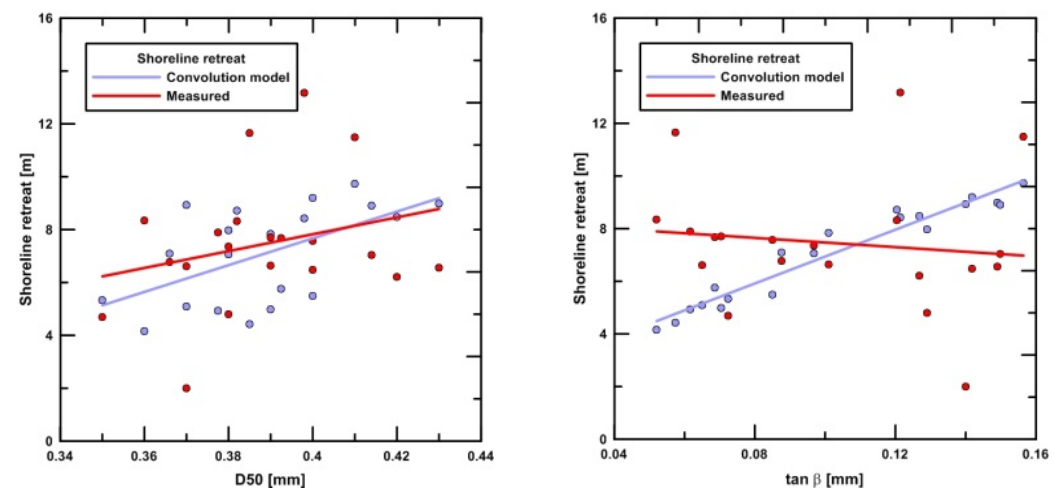

Figure 7. Assessment of ability of convolution models to predict the shoreline retreat considering dependence between shoreline retreat and $D_{50}$ (left), and shoreline retreat and $\tan \beta$ (right).

Fig. 7 shows a comparison between linear approximation of data clouds, describing shoreline retreat as a function of $\mathrm{D}_{50}$ and $\tan \beta$ obtained for both convolution model and measurements. It can be seen that the shoreline retreat is more dependent on $\mathrm{D}_{50}$ in comparison to $\tan \beta$. The biggest differences between calculated and measured retreat are observed in the middle part of the site, which can be attributed to the influence of the river mouth located in the middle part of the beach. Moreover, the differences in morphology between the northern and southern beach sections and the presence of a long-shore bartrough additionally influence the results.

\section{Hazard intensities and extents}

After application of the empirical models on regional scale, obtained extreme hazard series of TWLs and shoreline retreats were subjected to Extreme Value Analysis (Valchev et al. 2016) and hazard intensities relevant to return periods of 20, 50 and 100 years were determined.

Further in the process of hazard assessment, flooding hazard extents were determined using the "bathtub" approach or calculated through the overwash extent formulations (eq. 13-14) depending on the hinterland slope in each sector. Regarding the erosion hazard the extents of shoreline retreat were delineated as buffers along the coastline. For the beach sectors with presence of dunes it was found that they are eroded only in case of several very severe storms. After determination of the hazard extents flood and erosion polygons were outlined in GIS environment for further hazard assessment.

\section{Hazard assessment}

The coastal flooding hazard indicator $\left(i_{\text {cf }}\right)$ was calculated along the entire regional coast of Varna using the evaluated TWL for each sector. However, due to the wide variety of existing morphological settings (sandy beaches of variable width, rocky cliffs and artificial slopes) the evaluation was not done by the value of TWL itself. The area exposed to inundation was taken into account as well. To this end, the inundated areas $\left[\mathrm{m}^{2}\right]$ in all sectors were grouped in 10 classes, to which a weight, ranging from 0.05 to 1 , was given.

Then, a parameter weighted TWL was formulated by multiplying the given TWL to their respective weight. Thus, maximum weight was assigned to those values of TWL that inundated the largest hinterland areas. Subsequently, those values were ranked using the method of maximum breaks 
(Slocum, 1999) in attempt to consider individual data values and group those that are similar. To this end, data sample was ordered from low to high, the differences between adjacent values were computed, and the largest of these differences served as class breaks. The ranking intervals are listed in Table 4 .

\begin{tabular}{|ccc|}
\hline \multicolumn{2}{|c|}{ Table 4. Coastal flooding hazard indicator ranking. } \\
\hline \multicolumn{2}{|c|}{ Ranking intervals } & Rank values \\
\hline 0 & 0.75 & 1 \\
0.75 & 1.2 & 2 \\
1.2 & 1.6 & 3 \\
1.6 & 2.2 & 4 \\
2.2 & $<$ & 5 \\
\hline
\end{tabular}

The beach erosion hazard indicator $\left(i_{c e}\right)$ represented by the shoreline retreat was calculated along the entire regional coast of Varna. Due to different dimensions of sandy beaches within the study area, shoreline retreat was presented as percentage of the total berm width for each profile. The ranking intervals (Table 5) were then obtained using the maximum breaks method (Slocum, 1999).

\begin{tabular}{|c|c|c|}
\hline \multicolumn{2}{|c|}{ Retreat of the berm (\%) } & \multirow{2}{*}{$\begin{array}{c}\text { Rank values } \\
1\end{array}$} \\
\hline 1 & 35 & \\
\hline 36 & 45 & 2 \\
\hline 46 & 60 & 3 \\
\hline 61 & 80 & 4 \\
\hline 81 & 100 & 5 \\
\hline
\end{tabular}

Following the methods described above, the flooding and erosion hazard indicators $\left(i_{\mathrm{cf}}, \mathrm{i}_{\mathrm{ce}}\right)$ were calculated for return periods of 20,50 and 100 years along the entire regional coast of Varna. As an example of the flooding hazard assessment, the flooding hazard indicator values for $\operatorname{Tr}=100$ years are summarized in Table 6. There is also a representation through color mapping of the indicator values along the studied area for the same return period shown on Fig. 8.

\begin{tabular}{|c|c|c|}
\hline \multicolumn{3}{|c|}{ Table 6. Ranking of coastal flooding hazard indicator for Tr = 100 years. } \\
\hline Ranks & $\begin{array}{c}\text { Ranks } \\
\text { description }\end{array}$ & Sectors \\
\hline 1 & Very low & $\begin{array}{c}1,4,7,11,15,23,25,26,28,29,31,33,35,37-39, \\
41-43,55,56,60\end{array}$ \\
2 & Low & $2,6,13,16,22,34,40,50,54,58,59,61,63,65$ \\
3 & Moderate & $3,5,17,30,32,48,64$ \\
4 & High & $9,10,12,14,18,21,36,45,46,47,51,53,57,62$ \\
5 & Very high & $8,19,20,24,27,44,49,52$ \\
\hline
\end{tabular}

\begin{tabular}{|c|c|c|}
\hline \multicolumn{3}{|c|}{ Table 7. Ranking of coastal erosion hazard indicator for $\mathbf{T r}=\mathbf{1 0 0}$ years. } \\
\hline Ranks & $\begin{array}{c}\text { Ranks } \\
\text { description }\end{array}$ & Sectors \\
\hline 1 & Very low & $2-5,8,13,14,18,19,27,38,45-53,59,64$ \\
\hline 2 & Low & $6,11,17,31,37,54$ \\
\hline 3 & Moderate & $7,10,12,32,34,36,56,57,58$ \\
\hline 4 & High & $20,39,40,43,62,63$ \\
\hline 5 & Very high & $16,33,42,44,55,60,65$ \\
\hline
\end{tabular}

Results from calculation of the coastal erosion hazard indicator values for $\operatorname{Tr}=100$ years are summarized in Table 7, to show an example of the coastal erosion assessment along the study site. The 
indicator values along the studied area are presented for the same return period in Fig. 9 through color mapping. All the sectors mapped in grey color are either man modified environment such as Varna Port area and related infrastructure, or presented by very narrow rocky strips in front of cliffs or capes.
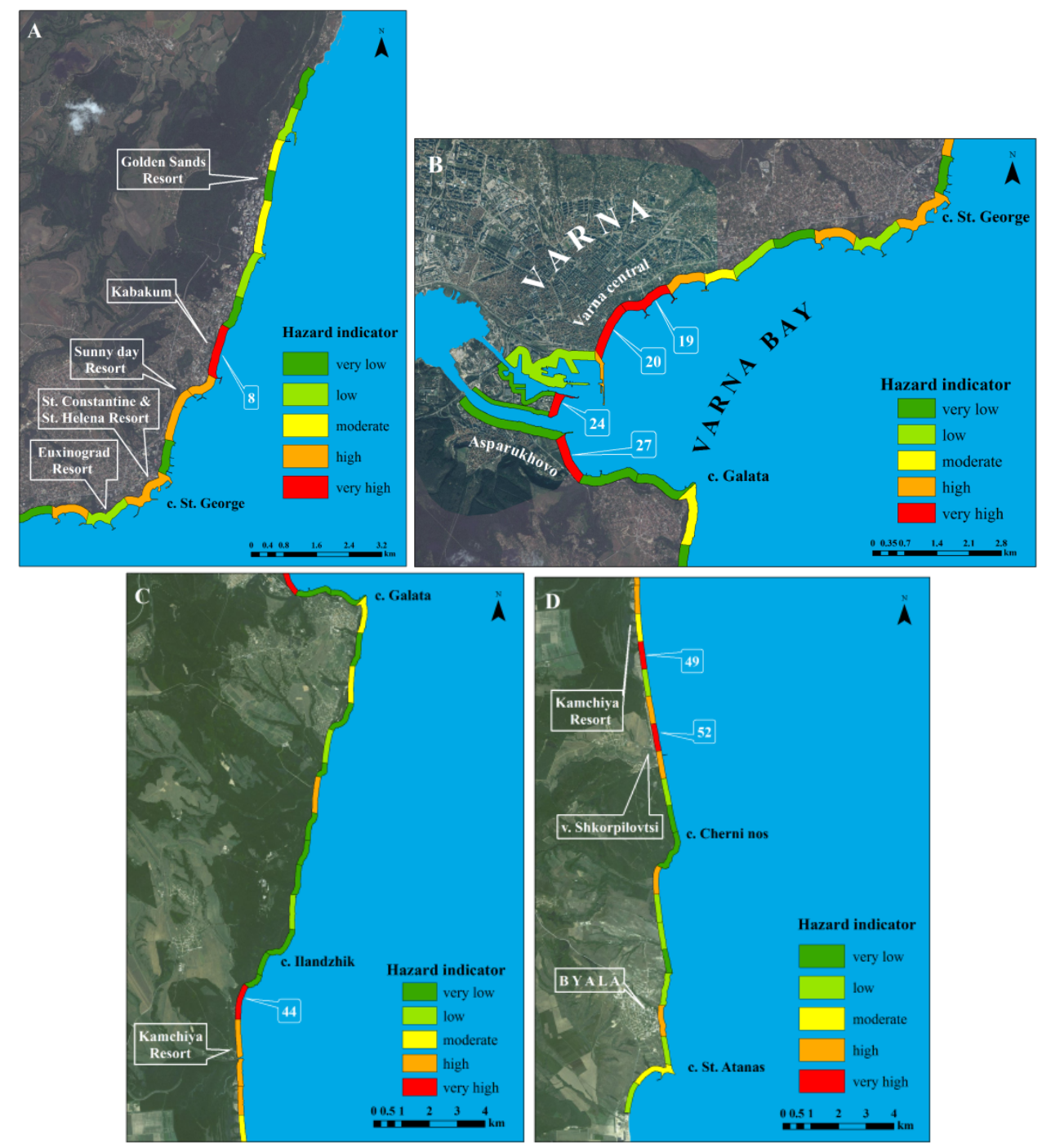

Figure 8. Coastal flooding hazard indicator $\left(i_{c}\right)$ along the regional coast of Varna; $T_{R}=100$ years

As mentioned above out of all 65 sectors 14 have 'high' susceptibility to flooding hazard, while 8 sectors are ranked as 'very high'. Reasons could be sought in the specificity of geomorphological settings defining the coastal response to given hazard intensities. With this respect, three groups of receptors can be determined within identified red sectors: 1) natural beaches, 2) man modified beaches and 3) artificial coasts. Natural beaches are geographically exposed to high-impact low-frequency storms hitting from the eastern half, while receptors in the latter two groups are somewhat protected from NE storms (except for Asparukhovo beach, sector 27).

Into the first group fall sectors 44,49 and 52. They are situated at open dissipative coast (Kamchiya-Shkorpilovtsi beach) with beach face slopes in the range of $0.08 \div 0.12$. The hinterland there is presented by low-laying lands protected by dunes. Estimated TWLs for these sectors varies between 3.4 and $3.9 \mathrm{~m}$. These levels are as half as high the maximum TWL modelled within the regional coastal area $(6.7 \mathrm{~m})$. For that reason, inundated zones were within the beach limits but sufficient to represent a major threat to coastal environment.

The second group includes sectors 8, 19, 20 and 27. They are situated in the northern part of the study site, which is under anthropogenic pressure due to presence of coastal protection structures causing sediment supply shortage. Sectors 8 (Kabakum beach) and 20 (Varna central beach) are 
presented by relatively long sandy beaches with beach face slopes 0.3 and 0.17 , respectively. Moreover, they are of varying widths as being narrow in their northern part and wider to the south. Estimated TWLs varied between 4.3 and $5.7 \mathrm{~m}$, which are among the highest. Another vulnerable sector within the group is 19 . The coast of the entire sector is protected by revetment, limited by two jetties with two small narrow sheltered beaches. Herein the estimated TWL was $5.14 \mathrm{~m}$ relevant to the revetment slope of 0.42 . The last sector 27 in this group is occupied by the long, wide and mild sloped (0.12) Asparukhovo beach backed by low-laying hinterland. Flooding potential was modelled with TWL $3.16 \mathrm{~m}$. Combination of the natural exposition of these sectors to forcing factors (surge and wave action) and the existing beach slopes led to the estimated hazard intensities, which caused inundation of entire beach bodies and even beyond impacting the hinterland and promenades.
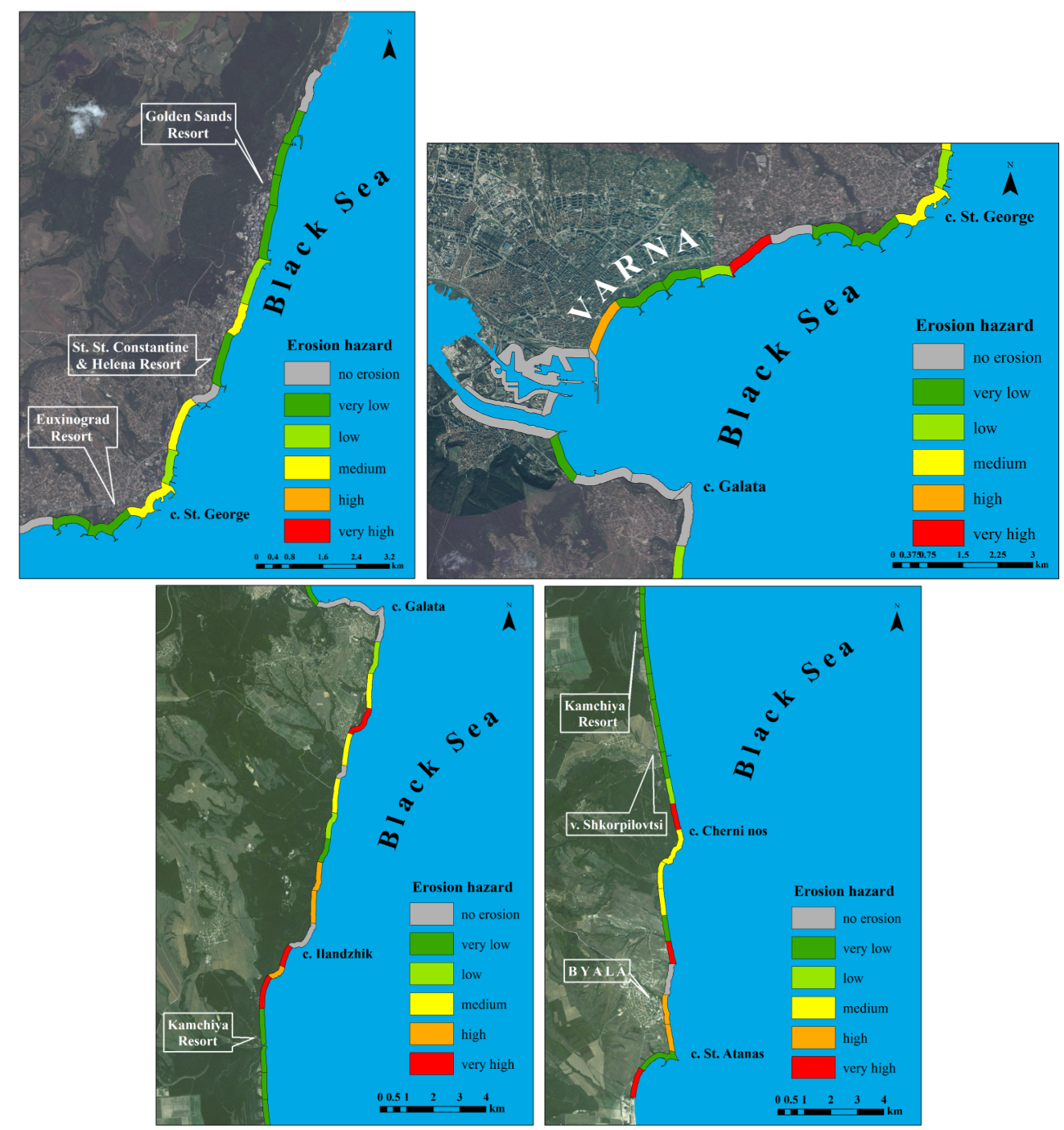

Figure 9. Coastal erosion hazard indicator $\left(i_{c e}\right)$ along the coast of Varna; $T R=100$ years

The third group is presented by sector 24 . At present, it is an entirely armoured forehead (slope 0.2 ) of artificially formed island - a remnant of the low-laying Varna sandy spit - situated between the two navigable canals. It comprises buildings, technical networks and facilities for industrial purposes. Herein, the estimated overwash extent exceeded $200 \mathrm{~m}$ being the main reason its hazard vulnerability to be qualified as 'very high'.

\section{CONCLUSIONS}

The study presented the process of calculation of maximum wave run-up and erosion at Varna regional coast (western Black Sea) using empirical models as a part of the hazard assessment. The methodology is quite complex and demands representative data describing geomorphological setting, 
spatial variability of hydraulic boundary conditions (surges and waves) as well as dedicated data form measurements to validate empirical models used for hazard evaluation.

Three empirical models were considered for calculation of maximum wave run-up on natural beach slopes. They were validated against field measurements to establish that the Holman was selected as most suitable to be applied to Varna regional coast. As for artificial and rocky slopes the EurOtop model was validated at a coastal revetment in Varna Bay. Furthermore, the convolution model employed for calculation of storm induced shoreline retreat was validated against field measurements for one event. It can be claimed that all models give satisfactory results except for reflective conditions.

The assessment of hazard intensities and their respective extents in the hinterland allowed for calculation of flooding and erosion hazard indicators for three return periods. These indicators were used to compare hazard conditions along the coast and to identify particularly susceptible to hazard impact sectors. The most endangered sectors are Kabakum beach; port, beaches and artificial island whitin Varna Bay; as well several sectors located along Kamchia-Shkorpilovtsi beach.

The coastal erosion hazard assessment shows that the most endangered sectors are located in the northern part of Varna Bay, to the south of cape Galata and cape Ilandzhik, one located at most southern part of Kamchia - Shkorpilovtsi beach, one in the most southernmost part of study site. All beaches that are in potential risk represent narrow sandy strips backed by cliffs. Comparison of results obtained for both hazard indicators suggest that the flooding hazard is more important for determining the coastal risk.

\section{Acknowledgments}

This work was supported by the European Community's 7th Framework Programme through the grant to RISC-KIT (Resilience-increasing Strategies for Coasts - Toolkit), contract no. 603458, Fund for Scientific Research affiliated to Ministry of Education and Science, Bulgaria, contract Д01-188, and contributions by partner institutes.

\section{REFERENCES}

Battjes, J.A. 1974. Surf similarity. Proceedings of the 14th International Conference of Coastal Engineering (American Society of Civil Engineers), 466-480.

Battjes, J.J.A. 1971. Runup distributions of waves breaking on slopes, Journal of the Waterways, Harbours and Coasts Engr. Div., ASCE, 97 WW1, 91-114.

Bruun, P. 1962. Sea level rise as a cause of shore erosion, Journal of Waterways and Harbors Division, $88(1), 117-130$.

Dean, R.G. and E.M Maurmeyer. 1983. Models for beach profile response. In: Komar, P. (Ed.), Handbook of Coastal Processes and Erosion. CRC Press, Boca Raton, 151- 165.

Dimitrov D., Nyagolov I., Balabanova S., Lisev N., Koshinchanov G., Korcheva A., Marinski Y., Pashova L., Grozdev D., Vasilev V., Bozhilov and N. Tsvetkova. 2013. Methods for assessment of flood hazard and flood risk, according to requirements of the EU Floods Directive 2007/60: Final Report, Black Sea Basin Directorate, Contract No D-30-62, 357 p. (In Bulgarian).

Donnelly, C. 2008. Coastal Overwash: Processes and Modelling. Ph.D. Thesis, University of Lund, $53 \mathrm{pp}$.

Douglass, S. 1992. Estimating extreme values of runup on beaches, Journal of Waterway, Port, Coastal and Ocean Engineering, 118(2): 220-224.

Edelman, T. 1972. Dune erosion during storm conditions. Proceedings of the 13th Coastal Engineering Conference, ASCE, 1305-1311.

Ferreira, O., C. Viavattene, J. Jimenes, A. Bole, T. Plomaritis, S. Costas and S. Smets. 2016. CRAF Phase 1, a framework to identify coastal hotspots to storm impacts, Proceedings of 3rd European Conference on Flood Risk Management FLOODrisk 2016, E3S Web of Conferences 7, 10002.

Garrity, N.J., R. Battalio, P.J. Hawkes and D. Roupe. 2006. Evaluation of the event and response approaches to estimate the 100-year coastal flood for Pacific coast sheltered waters, Proceeding of the 30th ICCE, ASCE, 1651-1663.

Hedges, T. and M. Reis. 1998. Random wave overtopping of simple seawalls: a new regression model. Water, Maritime and Energy Journal, 1(130), 1-10.

Holman, R.A. 1986. Extreme value statistics for wave run-up on a natural beach, Coastal Engineering, Elsevier, 9 (6), 527-544.

Hunt, I.A. 1959. Design of seawalls and breakwaters. Journal ofWaterways and Harbours Division, ASCE 85 (WW3), 123-152. 
Kobayashi, N. 1987. Analytical solution for dune erosion by storms, Journal of Waterway, Port, Coastal, and Ocean Engineering, 113(4), 401-418.

Komar, P. and M. Gaughan. 1973. Airy wave theory and breaker height prediction. Proceedings of the 13th Coastal Engineering Conference, ASCE, 405-418

Kriebel, D. and R. Dean. 1993. Convolution Method for Time-Dependent Beach-Profile Response, J. Waterway, Port, Coastal, Ocean Eng., 119(2), 204-226.

Larson, M., L. Erikson, and H. Hanson. 2004. An analytical model to predict dune erosion due to wave impact, Coastal Engineering, 51, 675-696.

Mase, H.1989. Randomwave run-up height on gentle slope. Journal of Waterway, Port, Coastal, and Ocean Engineering, 115(5), 649-661.

Nielsen, P. and D.J. Hanslow. 1991. Wave run-up distributions on natural beaches, Journal of Coastal Research, CERF. 7(4), 1139-1152.

Orton, P., S. Vinogradov, A. Blumberg and N. Georgas. 2014. Hydrodynamic mapping of future coastal flood hazards for New York City, Revised final project report, Stevens Institute of Technology, $36 \mathrm{pp}$

Overton, M.F., J.S. Fisher and T. Fenaish. 1987. Numerical analysis of swash forces on dunes. Proceedings of Coastal Sediments '87, ASCE, 632-641.

Overton, M.F., W.A. Pratikto, J.C. Lu and J.S. Fisher. 1994. Laboratory investigation of dune erosion as a function of sand grain size and dune density, Coastal Engineering, 23, 151- 165.

Park, H. and D. Cox. 2016. Empirical wave run-up formula for wave, storm surge and berm width, Coastal Engineering, Elsevier, 115, 67-78.

Pullen, T., N.W.H. Alsop, T. Bruce, A. Kortenhaus, H. Schüttrumpf and J.W. van der Meer. 2007. EurOtop. Wave overtopping of sea defenses and related structures: Assessment manual, Flood Risk Management: Research and Practice - Samuels et al. (eds.), Taylor \& Francis Group, London, 193 pp.

Reis, M., K. Hu, T. Hedges and H. Mase. 2008. A comparison of empirical, semiempirical and numerical wave overtopping models, Journal of Coastal Research, 24, 250-262.

Ruggiero, P., P.D. Komar, W.G. McDougal, J.J. Marra, and R.A. Beach. 2001. Wave runup, extreme water levels and the erosion of properties backing beaches, Journal of Coastal Research, 17(2), 407-419.

Sallenger, A.H. 2000. Storm impact scale for barrier islands, Journal of Coastal Research, 16 (3), 890 895.

Slocum T. A. 1999. Thematic cartography and Visualization. Upper Saddle River: Prentice Hall Inc.

Stanchev, H., R. Young and M. Stancheva. 2013. Integrating GIS and high resolution orthophoto images for the development of a geomorphic shoreline classification and risk assessment - a case study of cliff/bluff erosion along the Bulgarian coast, Journal of Coastal Conservation, 17(4), 719728 .

Stockdon, H. F., R.A. Holman, P.A. Howd and A.Jr. Sallenger. 2006. Empirical parameterization of setup, swash, and run-up, Coastal Engineering, Elsevier, 53(7), 573-588.

Trifonova E., N. Valchev N. Andreeva and P. Eftimova. 2012. Critical storm thresholds for morphological changes in the western Black Sea coastal zone, Geomorphology, Elsevier, 143-144, 81-94.

Valchev, N., E. Trifonova and N. Andreeva. 2012. Past and recent trends in the western Black Sea storminess, Nat. Hazards Earth Syst. Sci., 12, 1-17.

Valchev, N., N. Andreeva, P. Eftimova, B. Prodanov and I. Kotsev. 2016. Assessment of vulnerability to storm induced flood hazard along diverse coastline settings, Proceedings of 3rd European Conf. on Flood Risk Management, FLOODrisk 2016, E3S Web of Conferences 710002.

Van Dongeren, A., P. Ciavola, G. Martinez, C. Viavattene, S. DeKleermaeker, O. Ferreira, C. Costa and R. McCall. 2016. RISC-KIT: Resilience-increasing Strategies for Coasts, Proceedings of 3rd European Conf. on Flood Risk Management, FLOODrisk 2016, E3S Web of Conferences 717001.

Vellinga, P. 1986. Beach and dune erosion during storm surges. PhD thesis, Delft Hydraulics Communications No. 372, Delft Hydraulics Laboratory, Delft, The Netherlands.

Weggel R.J. 1972. Maximum breaker height.Journal of the Waterways, Harbors and Coastal Engineering Division, ASCE 1972, 98(4), 529-548

Wright, L.D. and A.D. Short. 1984. Morphodynamic variability of surf zones and beaches: a synthesis. Marine Geology, Elsevier, 56, 93-118. 